\title{
A GENERAL RESOURCE PORTFOLIO PLANNING MODEL FOR SMES UNDER DETERMINISTIC DEMAND ASSUMPTIONS
}

\author{
HaThi Xuan Chi, Phuc Hong Nguyen, Yardin Heidsyam, \\ Achmad Yasid, Moch Yasin, M Akmalul Ulya \\ Department of Industrial Management, School of Management \\ National Taiwan University of Science and Technology \\ No.43, Sec. 4, Keelung Road, Da'an District, Taipei City 106, Taiwan (R.O.C) \\ Phone: +886-2-2737-6341, Fax: +886-2-2737-6344
}

\begin{abstract}
Abstrak
Perusahaan skala kecil dan menengah membawa pengaruh yang tinggi bagi keseluruhan industry dan kontribusi yang penting bagi perkembangan ekonomi suatu negara. Bagaimanapun, UKM telah terbukti dapat menanggulangi permasalahan-permasalahan yang berkaitan dengan biaya yang tinggi dan investasi sumber daya, biaya pemesanan dan biaya inventory. Penelitian ini mengambil contoh perencanaan sumberdaya dan alokasi kapasitas yang dapat menanggulangi permasalahan ini secara optimal. Penelitian ini memiliki lima batasan yang berhubungan dengan perencanaan sumberdaya dan alokasi kapasitas dengan tujuan untuk memaksimalkan keuntungan. Pada penelitian ini, Algoritma Genetika digunakan untuk mencari solusi permasalahan yang optimal, dari beberapa percobaan yang telah dilakukan, terbukti bahwa Algoritma Genetika dapat secara efektif diimplementasikan pada model SME.
\end{abstract}

Abstract

Small and medium enterprises (SMEs) account a high percentage of the total industrial establishments and bring essential contribution to national economic development. However, SMEs have suffered from some problems associated with highly cost of resource investment, backorder cost and inventory cost. This study takes into account in term of resource planning and capacity allocation that can effectively deal with these problems. A new model with five constraints related to resource planning and capacity allocation to maximize profit for SMEs is developed. In this paper, genetic algorithm is employed to find the optimal solution. Through an example illustrated, the proposed model can effectively apply for SME model.

Keywords: resource planning, capacity allocation, SMEs, genetic algorithm

\section{INTRODUCTION}

Lumpy demands, short product lifecycle, intensive capital investment and thin profit margin make companies suffer and reduce their profits Resource planning and capacity allocations dealing with finding the optimal resource portfolio to fulfill demand are good option to solve these problems. By doing proper resource planning and capacity allocation, company can reduce the amount of invested capital on resources, rapidly response to the change of demand and maximize the long term profit (Wang, Chen, \& Wang, 2007); (Wang \& Chen, 2009). Unfortunately, making good resource planning and capacity allocation are not easy task because there are several constraints, characteristics, and methods that should be considered.
In recent decade, SMEs (small medium enterprises) play a key role in gross domestic product (GDP) of a nation, widely recognized in many countries and make in process of industrial development. It was noted that SMEs consist of $91-93 \%$ of the total industrial establishments in countries such as Singapore, Taiwan, Thailand and South Korea. In these countries, contributions of SMEs to employment ranged from 35 to nearly $61 \%$ with the contribution to value added ranging between 22 and $40 \%$ (Stiffung, 1990). Similar with companies, SMEs also face these kinds of problems. However, only a few studies consider capacity planning and research allocation for SMEs.

This paper aims to develop general model in the capacity planning and resource allocation that maximize profits in SME. Furthermore, this study focuses on: (1) determination on resource 
portfolio regarding several alternatives including purchasing, renting, transfer, and phase out; (2) determination on resource allocation in order to fulfill demand in each period while considering limited resource capability and capacity; (3) determination on inventory level on each period such that holding cost and backorder cost can be trade-off. Due to the complexity of the problems, soft computing approach - genetic algorithm (GA) - is used.

The rest of the paper is organized as follows. Section 2 reviews the related works. Section 3, section 4 , section 5 , and section 6 will discuss the mathematical problem, algorithm, output of algorithm, and sensitivity analysis. And the last, conclusion will be drawn in section 7 .

Resource planning and capacity allocation have been an interesting research topics which has attracted many researchers concern. In real industries, the terms-resource portfolio planning and task allocation-are closed each other but many previous works examined them separately for simplification.

Solving approaches in resource planning and capacity allocation can be separated into two categories: mathematical programming and softcomputing methods. Exact solution by using mathematical programming has been proven as an approach that gives best result in accuracy. Two famous applied methods in this area are linear programming (Rajagopalan, 1994); (Hung \& Leachman, A production planning methodology for semiconductor manufacturing based on interactive simulation and linear programming calculations, 1996); (Bashyam, 1996); (Hung and Wang, 1997) and mixed integer linear programming. However, these methods usually face the complexity of problems that impact to the solving time or exact solution never found (Wang, Chen, \& Wang, 2007).

The second approach, soft computing, can be used to deal with the complexity. This method also has been proven to give relative good accuracy compared with exact solution and in a shorter time. (Bard, Srinivasan, \& Tirupati, 1999) (Swaminathan, 2000); and (Merkle, Middendorf, \& Schmeck, 2002) used soft computing methods to address the capacity allocation and expansion problem. In line with the methods, genetic algorithm (GA) is the most concerned one has been used in solving this problem in comparison with the other methods. A simple GA was first proposed by (Holland, 1975). The GA methodology includes the representation of a chromosome structure, initial population, population size, selection probabilities, genetic operators, and termination conditions. A fitness function is then used to screen for good chromosomes. A GA to allocate capacity for orders and increased resource utilization and throughput was proposed by (Tiwari \& Vidyarth, 2000). By 2002 Wang and Lin tackled a capacity expansion and allocation problem for a high-tech manufacturing with a constrained budget using GA. (Wang \& Hou, 2003) also addressed the problem of capacity expansion and allocation in the semiconductor testing industry using GA.

From these literature reviews, GA seems a good choice in order to solve the capacity planning and resource allocation. Figure 1 gives the short information about the framework (adopted from Wang et al., 2007). The characteristics of considered problem here are multiple production horizon, several types of products, capital time value, resource throughput, constraint of asset and capital, limited budget, and the usage of multi-function resources.

To solve the problem, this paper use integer programming to find the best resource portfolio and inventory balance in order to maximize the profit under constraints. The constraints considered in the model are required numbers of main resources, inventory balance from net market demands, inventory or backorder cost equation, capital variation result due to purchasing or phasing out main resource, and capital limitation.

\section{METHODOLOGY}

This model considers balance of inventory and number of backorder to decide the adjusted number of main resources (such as by purchasing, phasing out, renting, or transferring) in order to get most efficient task allocation. The inputs used in the model are demands of each type of product in each period, unit profits of each type of product, main resource throughput, unit inventory and backorder cost of each type of product, unit purchasing, phasing out, and renting cost of main resource, and the interest rate. All of the inputs are under deterministic assumptions.

The outputs of the model are divided into two types: the capacity planning decision and capacity allocation decision. The capacity planning decision consists of the decision of resource portfolio: The capacity planning decision determines how many main and auxiliary resources that should be rented, purchased, and phased out while the capacity allocation 
decision determines how many products should be produced by each resource per period.

The further consideration and assumptions are used in the model as follows:

1. Each unit of product will be charged (inventory cost) at the end of each periods.

2. Backorders are considered in the model.

3. The salvage values of the resources are deterministically known.

4. The rate of utilization and throughput of the resources are deterministically known.

5. The usage of multi-function resource means that every type of resource can be used to produce several types of products.

6. The profit gained in period $p$ will be used for increasing the resource in period $p+1$.

The detail explanations of notations used in this model are listed in appendix A.

All of the constraints are developed follows:

1. Required numbers of main resources.

Number of main resources $m$ in period $p$ should be greater or equal with the minimum number of main resources $m$ to fulfill the demands in period $\mathrm{p}$.

$$
\begin{aligned}
& K_{p, m}+ \sum_{z} X_{p, m, z} \geq \sum_{t} \frac{c_{m, t} Q_{p, m, t}}{r_{m, t} W_{p, m} Y_{p, m}} \\
& \forall p, m
\end{aligned}
$$

2. Inventory balance from net market demands. Inventory will occur if the stock and the amount of production are higher than the demand. Here the balance of inventory at the end of period $\mathrm{p}$ is computed by adding the net inventory level of product $t$ in period $\mathrm{p}-1$ with the number of product $t$ produced in period $\mathrm{p}$ minus with the real demand of product $\mathrm{t}$ in period $\mathrm{p}$.

$S_{p, t}=S_{p-1, t}+\sum_{m \in M} c_{m, t} Q_{p, m, t}-o_{p, t}$

3. Inventory or backorder cost equation.

If inventory balance of product $t$ at the end of period $p$ occurs then inventory cost occurs, otherwise, backorder cost occurs. In this paper the value of inventory or backorder cost in period $\mathrm{p}$ is transform into present value (by using to find present given future).

$Z_{p, t}=\left\{\begin{array}{l}\frac{\alpha_{p, t}\left(S_{p-1, t}\right)}{\left(1+I_{p}\right)^{p}}, \text { if } S_{p-1, t} \geq 0 \\ \frac{\beta_{p, t}\left|s_{p-1, t}\right|}{\left(l+I_{p}\right)^{p}}, \text { otherwise }\end{array}\right.$

Where:

$\alpha=$ unit inventory cost of product $t$ in period $p$,

$\beta=$ unit backorder cost of product $t$ in period $p$

4. Capital variation result due to purchasing or phasing out main resource.

Buying and selling main resources will affect the capital. G_(p,m) is the change in capital due to the procurement of main resource $m$ from period $p-1$ to period $p$ if the number of main resource of period $\mathrm{p}$ greater than $\mathrm{p}-1$; otherwise, phasing out.

$$
\begin{aligned}
& G_{p, m}= \\
& \left\{\begin{array}{cc}
e_{p, m}\left(K_{p, m}-K_{p-1, m}\right), & \text { if } K_{p, m}-K_{p-1, m} \geq 0 \\
d_{p, m}\left(K_{p, m}-K_{p-1, m}\right), & \text { otherwise }
\end{array} \forall p, m\right.
\end{aligned}
$$

\section{Capital limitation.}

The capital in period $\mathrm{p}$ is computed by calculating the remaining budget minus by cost of outsourcing main and auxiliary resources and purchasing cost of main and auxiliary resources and add by production profit.

$$
\begin{aligned}
F_{p}=F_{p-1}\left(1+I_{p-1}\right) & -\sum_{m, z} u_{p, m, z} X_{p, m, z} \\
& -\left(\sum_{m} G_{p, m}\right) \\
& +\sum_{m, t} B_{m, t} Q_{p, m, t} \forall p
\end{aligned}
$$

And the objective function of the model is formulated as:

$$
\begin{aligned}
\boldsymbol{\theta}=\frac{\boldsymbol{F}_{p^{\text {end }}}}{\prod_{p \in P}\left(1+I_{p}\right)} & \\
& -\sum_{m \in M}\left(e_{m}-d_{m}\right)\left(K_{m}\right. \\
& \left.-K_{0, m}\right)-\sum_{p \in P, t} Z_{p, t}
\end{aligned}
$$

The problem here is complex. The complexity will increase dramatically upon increasing $\mathrm{p} /$ du(d)type, periods of production horizon, the amount of initial budget, and the interest rate. This high complexity makes the searching of exact solution becomes very difficult. To handle this, we use GA to get the solution.

\subsection{The Algorithm}

Genetic Algorithm (GAs) is adaptive heuristic search algorithm premised on the evolutionary ideas of natural selection and genetic. The basic concept of GAs is designed to simulate process in natugral system necessary for evolution. GA is identical with random number, because most of processes in GA were generated by random number, such as mutation, cross-over, etc. Many of the real world problems involved finding optimal parameters, which might prove difficult for traditional methods but ideal for GA [17]. GAs is suitable to find global optimum for nonlinear problems. In this paper, GAs is used to find the optimum value of the profit. There are three important parameters of the GA were used in this paper. 
Chi, dkk., A General Resource Portfolio Planning Model for SMEs under Deterministic Demand..

1. Population size. Population size means how many chromosomes are in population (in one generation). If there are too few chromosomes, GA have a few possibilities to perform crossover and only a small part of search space is explored. On the other hand, if there are too many chromosomes, GA slows down. Research shows that after some limit (which depends mainly on encoding and the problem) it is not useful to increase population size, because it does not make solving the problem faster [16]. In this paper we used some population sizes $(70,80,90,100)$ and we define the chromosome same as the decision variables.

$K_{m} \quad$ Number of in-house main resource type min period $\mathrm{p} . \mathrm{K}_{\mathrm{m}} \quad \mathrm{Z}^{+}$

$\mathrm{K}_{\mathrm{a}}^{\mathrm{h}} \quad$ Number of in-house auxiliary resource type a (of the $\mathrm{h}$ category) in period $\mathrm{p} . \mathrm{K}_{\mathrm{p} ; \mathrm{a}}^{\mathrm{h}}$ $\mathrm{Z}^{+}$

$X_{\mathrm{p}, \mathrm{m}, \mathrm{z}} \quad$ Number of main resource type $\mathrm{m}$ associated with resource acquisition alternative $\mathrm{z}$ in period $p . \mathrm{X}_{\mathrm{p}, \mathrm{m}, \mathrm{z}} \mathrm{Z}^{+}$

$\mathrm{X}_{\mathrm{p}, \mathrm{a}, \mathrm{z}}^{\mathrm{h}}$ Number of auxiliary resource type $\boldsymbol{a}$ (of the $\mathrm{h}$ category), associated with resource acquisition ternativez in period $\mathrm{p} . \mathrm{X}_{\mathrm{p} ; \mathrm{a} ; \mathrm{z}}^{\mathrm{h}} \mathrm{Z}^{+}$.

$Q_{p, m, t} \quad$ Quantity of product $\mathrm{t}$ produced by main re source type $m$ in period $p . Q_{p, m, t} R^{+}$.

$Q_{p, a, m, t}^{h}$ Quantity of productt produced by auxiliary resource type $\boldsymbol{a}$ (of the $\boldsymbol{h}$ category), associated with main resource type $\boldsymbol{m}$ in period $p . \mathrm{Q}_{\mathrm{p} ; \mathrm{a} ; \mathrm{m} ; \mathrm{t}}^{\mathrm{h}} \mathrm{R}^{+}$.

$S_{p, t} \quad$ Capacity loading quantity of product in the end of period $\boldsymbol{p}$ in scenario. $S_{\mathrm{p}, \mathrm{t}} \mathrm{Z}$

$\mathrm{V}_{p, t} \quad$ The capacity loading cost of product $t$ in period $\boldsymbol{p}$.

2. Mutation. Mutation probability says how often will be parts of chromosome mutated. If there is no mutation, offspring is taken after crossover (or copy) without any change. If mutation is performed, part of chromosome is changed. If mutation probability is $100 \%$, whole chromosome is changed, if it is $0 \%$, nothing is changed. Mutation is made to prevent falling GA into local extreme, but it should not occur very often, because then GA will in fact change to random search [16]. In this paper, there are not all of the variables will be mutated. There are Qp,m,t, Qp,a,m,t, $\mathrm{Xp}, \mathrm{a}, \mathrm{z}, \mathrm{xp}, \mathrm{m}, \mathrm{z}, \mathrm{Km}, \mathrm{Kh}, \mathrm{p}, \mathrm{a}$ and the range of the mutation numbers that will applied to the gene are varying(1-5, 1-6, 1-7, 1-8, 1-9, 1-10).

3. Decision Range. We add decision range to improve the result. Decision range is the limitation range of generated number in chromosome after mutation process. For example if the decision range is 5 , then the generated chromosome value can only be $1,2,3,4$, and 5 ; if the decision range is 6 , then the generated chromosome value can only be $1,2,3,4,5$, and 6 . We run the algorithm several times using decision range $5,6,7,8,9,10$ to know which one is the best decision range for this problem.

4. Iteration. Iteration is generation number of the GAs. 1 iteration contain of several processes, such as chromosome generation, selection, reproduction, mutation, and repair mechanism. The processes inside the GAs were shown in the figure 1. In this paper, the number of iteration were varying (100 and 200), the GAs processes will be stop when the number of iteration were fulfilled. For example for 100 iteration, the first iteration will contain of chromosome generation, reproduction, mutation, and repair mechanism. After repair mechanism finished, the second iteration will be begun. The process inside both of the first and the second iteration were the same. The second iteration will contain of generation, reproduction, mutation, and repair mechanism.

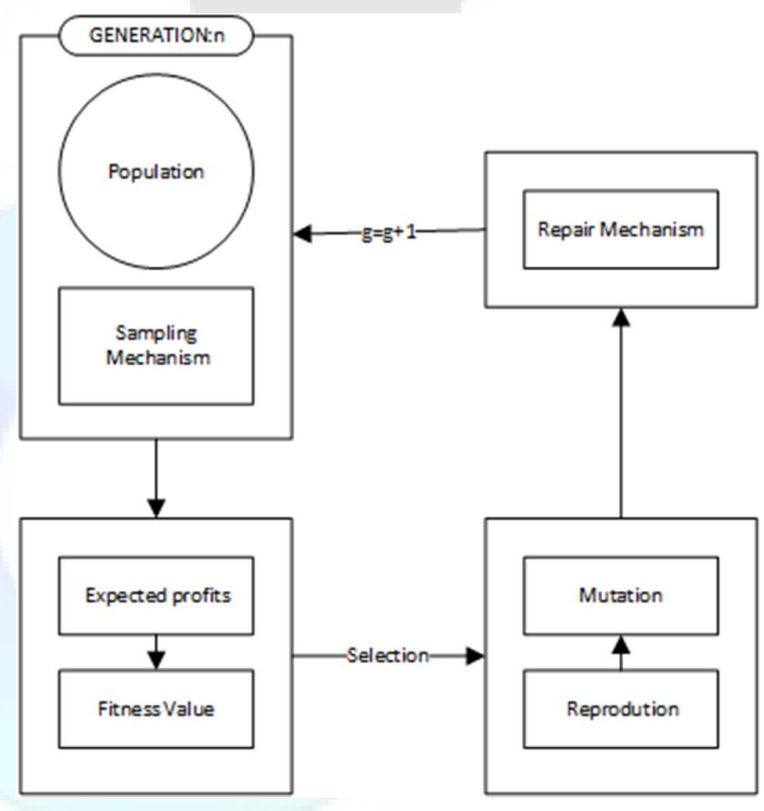

Figure 1. The GA.

\section{RESULTS and EXPLANATION}

As mentioned above, this model aims to answer optimal solution related to resource portfolio and resource allocation and also the inventory level. In order to prove our model, we applied this model by using the data provided by (Wang, Chen, \& Wang, 2007). We got following results.

For example, from tabel 1 , the best number machine acquisition for period 1 by renting $(\mathrm{z}=$ 1 ) is 3 units machine type 1,1 unit machine type 2 , and 1 unit machine type 3 . 
Table 1. Acquisition number of main machine for $\mathrm{z}=1$.

\begin{tabular}{cccc}
\hline Period & $\begin{array}{c}\text { Main } \\
\text { Machine } \\
\mathbf{1}\end{array}$ & $\begin{array}{c}\text { Main } \\
\text { Machine } \\
\mathbf{2}\end{array}$ & $\begin{array}{c}\text { Main } \\
\text { machine } \\
\mathbf{3}\end{array}$ \\
\hline 1 & 3 & 1 & 1 \\
2 & 5 & 1 & 1 \\
3 & 5 & 1 & 1 \\
4 & 5 & 2 & 1 \\
5 & 3 & 1 & 5 \\
6 & 2 & 5 & 4 \\
\hline
\end{tabular}

Table 2. Acquisition number of main machine for $\mathrm{z}=2$.

\begin{tabular}{cccc}
\hline Period & $\begin{array}{c}\text { Main } \\
\text { Machine } \\
\mathbf{1}\end{array}$ & $\begin{array}{c}\text { Main } \\
\text { Machine } \\
\mathbf{2}\end{array}$ & $\begin{array}{c}\text { Main } \\
\text { machine } \\
\mathbf{3}\end{array}$ \\
\hline 1 & 1 & 3 & 3 \\
2 & 4 & 4 & 4 \\
3 & 2 & 3 & 2 \\
4 & 2 & 1 & 4 \\
5 & 1 & 2 & 4 \\
6 & 3 & 1 & 3 \\
\hline
\end{tabular}

Table 3. Number of main resource

\begin{tabular}{cccc}
\hline \multirow{2}{*}{ Period } & \multicolumn{3}{c}{ Number of main resources } \\
\cline { 2 - 4 } & $\mathbf{1}$ & $\mathbf{2}$ & $\mathbf{3}$ \\
\hline $\mathbf{1}$ & 3 & 5 & 0 \\
$\mathbf{2}$ & 4 & 3 & 0 \\
$\mathbf{3}$ & 4 & 5 & 0 \\
$\mathbf{4}$ & 2 & 5 & 0 \\
$\mathbf{5}$ & 1 & 5 & 0 \\
$\mathbf{6}$ & 4 & 2 & 0 \\
\hline
\end{tabular}

Table 4. Number of product produced by main machine for $\mathrm{t}=1$.

\begin{tabular}{cccc}
\hline \multirow{2}{*}{ Period } & \multicolumn{3}{c}{$\begin{array}{c}\text { Number of product produced } \\
\text { by main machine M }\end{array}$} \\
\cline { 2 - 4 } & $\mathbf{1}$ & $\mathbf{2}$ & $\mathbf{3}$ \\
\hline $\mathbf{1}$ & 7 & 12 & 0 \\
$\mathbf{2}$ & 9 & 12 & 0 \\
$\mathbf{3}$ & 10 & 6 & 0 \\
$\mathbf{4}$ & 11 & 9 & 0 \\
$\mathbf{5}$ & 8 & 8 & 0 \\
$\mathbf{6}$ & 5 & 11 & 0 \\
\hline
\end{tabular}

Table 5. Number of product produced by main machine for $\mathrm{t}=2$.

\begin{tabular}{cccc}
\hline \multirow{2}{*}{ Period } & \multicolumn{2}{c}{$\begin{array}{c}\text { Number of product produced by } \\
\text { main machine } M\end{array}$} \\
\cline { 2 - 3 } & 1 & 2 & 3 \\
\hline
\end{tabular}

\begin{tabular}{cccc}
\hline $\mathbf{1}$ & 11 & 0 & 9 \\
$\mathbf{2}$ & 7 & 0 & 10 \\
$\mathbf{3}$ & 10 & 0 & 4 \\
$\mathbf{4}$ & 13 & 0 & 7 \\
$\mathbf{5}$ & 4 & 0 & 11 \\
$\mathbf{6}$ & 13 & 0 & 12 \\
\hline
\end{tabular}

Table 6 . Number of product produced by main machine for $\mathrm{t}=3$.

\begin{tabular}{cccc}
\hline \multirow{2}{*}{ Period } & \multicolumn{2}{c}{$\begin{array}{c}\text { Number of product produced by } \\
\text { main machine } \mathbf{M}\end{array}$} \\
\cline { 2 - 4 } & $\mathbf{1}$ & $\mathbf{2}$ & $\mathbf{3}$ \\
\hline $\mathbf{1}$ & 0 & 7 & 10 \\
$\mathbf{2}$ & 0 & 6 & 10 \\
$\mathbf{3}$ & 0 & 5 & 10 \\
$\mathbf{4}$ & 0 & 9 & 8 \\
$\mathbf{5}$ & 0 & 13 & 11 \\
$\mathbf{6}$ & 0 & 13 & 10 \\
\hline
\end{tabular}

\subsection{Sensitivity analysis}

The effect of different GA parameters on objective values is reported in figure 2 and the detail about the result is explained in appendix. As can be seen, decision range can increase and decrease the result of the profit significantly. The lower the decision range, the higher the sum of profit. This also confirm that if we know the decision range, the output of the result can be controlled to. We get a maximum profit when decision range is 5 , mutation rate 0.2 , iteration 100, and number of population size is 70.

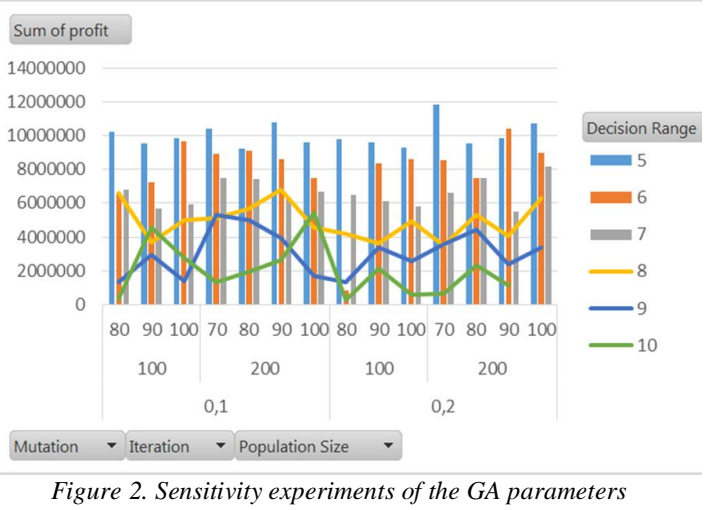

\section{CONCLUSION and FURTHER RESEARCH}

This paper develops a new model possessing some advantages to deal with capacity planning and resource allocation problems. The proposed model gives guidance to make a right decision for purchasing, selling, renting and allocating machine economically in order to produce the order. By applying the proposed model, the invested money for resource, backorder and 
Chi, dkk., A General Resource Portfolio Planning Model for SMEs under Deterministic Demand..

inventory cost can be minimized, result in maxmaximizing long term profit.

\section{REFERENCES}

Bard, J., Srinivasan, K., \& Tirupati, D., 1999. An optimization approach to capacity expansion in semiconductor manufacturing facilities. International Journal of Production Research, 3359-3382.

Bashyam, T., 1996. Competitive capacity expansion under demand uncertainty. European Journal of Operational Research 95, 89-114.

Holland, J. H., 1975. Adaptation in Natural and Artificial Systems. Detroit MI: University of Michigan Press.

Huin, S., 2004. Managing deployment of ERP systems in SMEs using multi-agents. International Journal of Project Management, 22, 511-517.

Hung, Y., \& Leachman, R., 1996. A production planning methodology for semiconductor manufacturing based on interactive simulation and linear programming calculations. IEEE Transactions on Semiconductor manufacturing 9, 257-269.

Hung, Y., \& Wang, Q., 1997. A new formulation technique for alternative material planning - an approach for semiconductor bin allocation planning. Computer and Industrial Engineering 32, 281-297.

Merkle, D., Middendorf, M., \& Schmeck, H. 2002. Ant colony optimization for resourceconstrained project scheduling. IEEE Transactions on Evolutionary Computation 6, 333-346.

Rajagopalan, S., 1994. Capacity expansion with alternative. European Journal of Operational Research, 392-402.

Stiffung, F.-E., 1990. Promotion of SME's: Policy environmental and institutional framework. ISI Regional Workshop. Kuala Lumpur.
Swaminathan, J., 2000. Tool capacity planning for semiconductor fabrication facilities under demand uncertainty. European Journal of Operational Research 120, 545558.

Tiwari, M., \& Vidyarth, N. K., 2000. Solving machine loading problems in a flexible manufacturing system using a genetic algorithm based heuristic approach. International Journal of Production Research 38 , 3357-3384.

Wang, K. J., \& Chen, M.-J., 2009. Cooperative capacity planning and resource allocation by mutual outsourching using ant algorithm in a decentralized supply chain. Expert Systems with Applications, 36, 2831-2842.

Wang, K. J., \& Hou, T., 2003. Modeling and resolving the joint problem of capacity expansion and allocation with multiple resources and limited budget in semiconductor testing industry. International Journal of Production Research 41, 3217-3235.

Wang, K.-J., Wang, S. -M., \& Yang, S.-J., 2007. A resource portfolio model for equipment investment and allocation of semiconductor testing industry. European Journal of Operational Research, 179, 390-403.

Wang, S., Chen, J., \& Wang, K.-J. 2007. Resource portfolio planning of make-tostock products using a constraint programming-based genetic algorithm. Omega, 35, 237-246.

http://www.obitko.com/tutorials/geneticalgorithms/parameters.php. Accessed on January, 2013.

http://www.doc.ic.ac.uk/ nd/surprise_96/journal /vol4/tcw2/report.html. Accessed on January, 2013.

Wu, S. H., Fuh, J. Y., \& Nee, A. Y., 2007. Concurent process planning and schedulling in distributed vistual manufacturing. IIE Transactions, 34(1), 7789. 


\section{Appendix}

Parameters are the variables that the value are previously known. The parameters used in the paper are:

$c_{m, t}$ Product-resource capabilities for product $t$ associated with main resource type $\boldsymbol{m}$.

This is a $0-1$ parameter. $\mathrm{c}_{\mathrm{m}, t}=1$ if main resource type $m$ can conduct product $t$; and otherwise.

$d_{m}$ Unit salvage value of phasing out main resource type $\boldsymbol{m} . \mathrm{d}_{\mathrm{m}}$ can has positive or negative value.

$e_{m}$ Unit cost of purchasing a main resource type $\boldsymbol{m}$

$I_{p} \quad$ Capital interest rate in period $\boldsymbol{p}$

$j_{p, t}$ The unit excess production cost of product $\boldsymbol{t}$ in period $\boldsymbol{p}$

$K_{0, m}^{h}$ Number of auxiliary resource type $\boldsymbol{a}$ (of the $\boldsymbol{h}$ category) in the initial period

$K_{0, m}$ Number of main resource type $\boldsymbol{m}$ in the initial period $\boldsymbol{p}$

$l_{p, t}$ The unit lack production cost of product $t$ in period $\boldsymbol{p}$

$o_{p, t} \quad$ Market demand for product $\boldsymbol{t}$ in period $\boldsymbol{p}$

$r_{m, t}$ Theoretical throughput of product $\boldsymbol{t}$ conducted by main resource type $\boldsymbol{m}$

$r_{m, a, t}^{h} \quad$ Theoretical throughput of product $t$ conducted by auxiliary resource type $\boldsymbol{a}$ (of the $\boldsymbol{h}$ category), associated with main resource type $\boldsymbol{m}$

$u_{\mathrm{p}, \mathrm{m}, \mathrm{z}}$ Unit cost of main resource type $\boldsymbol{m}$ obtained by outsourcing alternative $z$ in period $p$

$u_{p, a, z}^{h} \quad$ Unit cost of auxiliary resource type $\boldsymbol{a}$ (of the $\boldsymbol{h}$ category) obtained by outsourcing alternative $z$ in period $p$

$w_{\mathrm{p}, \mathrm{m}} \quad$ Working hours of main resource type $\mathrm{m}$ in period $\boldsymbol{p}$

$w_{p, a}^{h} \quad$ Working hours of auxiliary resource type a (of the $\boldsymbol{h}$ category) in period $\boldsymbol{p}$

$y_{\mathrm{p}, \mathrm{m}} \quad$ Target utilization of main resource type $\mathrm{m}$ in period $\boldsymbol{p}$

$y_{p, a}^{h} \quad$ Target utilization of auxiliary resource type $\boldsymbol{a}$ (of the $\boldsymbol{h}$ category) in period $\boldsymbol{p}$

$\alpha_{p, t}$ Inventory cost of each unit of the product type $\boldsymbol{t}$ at period $\boldsymbol{p}$.

$\beta_{\mathrm{p}, t}$ : Backorder cost of each unit of the product type $\boldsymbol{t}$ at period $\boldsymbol{p}$.

$\mathrm{z}_{\mathrm{p}, t}$ : Backorder cost if $\mathrm{k}_{\mathrm{p}-1, t}<0$, inventory cost otherwise.

$\mathrm{k}_{\mathrm{p}-1, t}:$ Inventory level at the period $(p-1)$ of the product type $t$.

$\mathrm{G}_{\mathrm{p}, \mathrm{m}}$ : The change in capital due to the procurement of main resource type $\mathrm{m}$ from period $\boldsymbol{p}-1$

to period $\boldsymbol{p}$

$\mathrm{G}_{\mathrm{p}, \mathrm{a}}^{\mathrm{h}}$ : The change in capital due to the procurement of main resource type a (of the $h$ kind)

\section{Parameters}

Auxiliary resource from period $p-1$ to the period $p$

\section{Decision Variables}

Decision variables are variables that the value are tried to find in order to obtain the objective function.

The decision variables used in the paper are:

$\mathrm{K}_{\mathrm{m}} \quad$ Number of in-house main resource type min period $\mathrm{p} . \mathrm{K}_{\mathrm{m}} \in \mathrm{Z}^{+}$

$\mathrm{K}_{\mathrm{a}}^{\mathrm{h}} \quad$ Number of in-house auxiliary resource type a (of the $\mathrm{h}$ category) in period $\mathrm{p} . \mathrm{K}_{\mathrm{p} ; \mathrm{a}}^{\mathrm{h}} \in \mathrm{Z}^{+}$

$X_{\mathrm{p}, \mathrm{m}, \mathrm{z}} \quad$ Number of main resource type $\mathrm{m}$ associated with resource acquisition alternative $\mathrm{z}$ in period $p . \mathrm{X}_{\mathrm{p}, \mathrm{m}, \mathrm{z}} \in \mathrm{Z}^{+}$

$\mathrm{X}_{\mathrm{p}, \mathrm{a}, \mathrm{z}}^{\mathrm{h}}$ Number of auxiliary resource type $\boldsymbol{a}$ (of the $\mathrm{h}$ category), associated with resource acquisition ternativez in period $\mathrm{p} . \mathrm{X}_{\mathrm{p} ; \mathrm{a} ; \mathrm{z}}^{\mathrm{h}} \in \mathrm{Z}^{+}$.

$Q_{p, m, t} \quad$ Quantity of product $\mathrm{t}$ produced by main re source type $\mathrm{m}$ in period $\mathrm{p} . \mathrm{Q}_{\mathrm{p}, \mathrm{m}, \mathrm{t}} \in \mathrm{R}^{+}$.

$Q_{p, a, m, t}^{h}$ Quantity of productt produced by auxiliary resource type $\boldsymbol{a}$ (of the $\boldsymbol{h}$ category), associated with main resource type $\boldsymbol{m}$ in period p. $\mathrm{Q}_{\mathrm{p} ; \mathrm{a} ; \mathrm{m} ; \mathrm{t}}^{\mathrm{h}} \in \mathrm{R}^{+}$.

$S_{p, t} \quad$ Capacity loading quantity of product in the end of period $\boldsymbol{p}$ in scenario. $\mathrm{S}_{\mathrm{p}, \mathrm{t}} \in \mathrm{Z}$

$\mathrm{V}_{p, t} \quad$ The capacity loading cost of product $t$ in period $p, \mathrm{~V}_{p, t} \mathrm{R}$

\section{The results of the GA.}

\begin{tabular}{|c|c|c|c|c|}
\hline Iteration & $\begin{array}{c}\text { Decision } \\
\text { Range }\end{array}$ & $\begin{array}{c}\text { Mutation } \\
\text { chance }\end{array}$ & $\begin{array}{c}\text { Population } \\
\text { size }\end{array}$ & profit \\
\hline 200 & 5 & 0,1 & 70 & $10.421 .629,73$ \\
\hline 200 & 6 & 0,1 & 70 & $8.935 .484,06$ \\
\hline 200 & 7 & 0,1 & 70 & $7.497 .063,85$ \\
\hline 200 & 8 & 0,1 & 70 & $5.096 .355,70$ \\
\hline 200 & 9 & 0,1 & 70 & $5.308 .446,28$ \\
\hline 200 & 10 & 0,1 & 70 & $1.329 .718,94$ \\
\hline 200 & 5 & 0,2 & 70 & $11.856 .311,67$ \\
\hline 200 & 6 & 0,2 & 70 & $8.537 .751,21$ \\
\hline 200 & 7 & 0,2 & 70 & $6.641 .579,51$ \\
\hline 200 & 8 & 0,2 & 70 & $3.515 .353,44$ \\
\hline 200 & 9 & 0,2 & 70 & $3.541 .982,22$ \\
\hline 200 & 10 & 0,2 & 70 & $625.819,86$ \\
\hline 100 & 5 & 0,1 & 80 & $10.205 .583,49$ \\
\hline 100 & 6 & 0,1 & 80 & $6.586 .404,56$ \\
\hline 100 & 7 & 0,1 & 80 & $6.792 .421,72$ \\
\hline 100 & 8 & 0,1 & 80 & $6.596 .192,41$ \\
\hline 100 & 9 & 0,1 & 80 & $1.322 .451,39$ \\
\hline 100 & 10 & 0,1 & 80 & $353.322,69$ \\
\hline 100 & 5 & 0,2 & 80 & $9.785 .884,70$ \\
\hline 100 & 6 & 0,2 & 80 & $854.973,56$ \\
\hline 100 & 7 & 0,2 & 80 & $6.465 .355,23$ \\
\hline
\end{tabular}


Chi, dkk., A General Resource Portfolio Planning Model for SMEs under Deterministic Demand..

\begin{tabular}{|c|c|c|c|c|c|c|c|c|c|}
\hline Iteration & $\begin{array}{c}\text { Decision } \\
\text { Range }\end{array}$ & $\begin{array}{c}\text { Mutation } \\
\text { chance }\end{array}$ & $\begin{array}{c}\text { Population } \\
\text { size }\end{array}$ & profit & Iteration & $\begin{array}{c}\text { Decision } \\
\text { Range }\end{array}$ & $\begin{array}{c}\text { Mutation } \\
\text { chance }\end{array}$ & $\begin{array}{c}\text { Population } \\
\text { size }\end{array}$ & profit \\
\hline 100 & 8 & 0,2 & 80 & $4.196 .726,30$ & 200 & 10 & 0,1 & 90 & $2.615 .238,59$ \\
\hline 100 & 9 & 0,2 & 80 & $1.340 .688,32$ & 200 & 5 & 0,2 & 90 & $9.854 .305,38$ \\
\hline 100 & 10 & 0,2 & 80 & $273.394,28$ & 200 & 6 & 0,2 & 90 & $10.396 .883,80$ \\
\hline 200 & 5 & 0,1 & 80 & $9.202 .172,17$ & 200 & 7 & 0,2 & 90 & $5.499 .658,99$ \\
\hline 200 & 6 & 0,1 & 80 & $9.125 .336,21$ & 200 & 8 & 0,2 & 90 & $4.086 .084,09$ \\
\hline 200 & 7 & 0,1 & 80 & $7.428 .836,65$ & 200 & 9 & 0,2 & 90 & $2.394 .000,31$ \\
\hline 200 & 8 & 0,1 & 80 & $5.688 .397,52$ & 200 & 10 & 0,2 & 90 & $1.158 .456,51$ \\
\hline 200 & 9 & 0,1 & 80 & $5.019 .839,47$ & 100 & 5 & 0,1 & 100 & $9.846 .705,98$ \\
\hline 200 & 10 & 0,1 & 80 & $1.930 .532,55$ & 100 & 6 & 0,1 & 100 & $9.669 .016,18$ \\
\hline 200 & 5 & 0,2 & 80 & $9.556 .902,00$ & 100 & 7 & 0,1 & 100 & $5.916 .371,90$ \\
\hline 200 & 6 & 0,2 & 80 & $7.489 .474,59$ & 100 & 8 & 0,1 & 100 & $4.979 .391,01$ \\
\hline 200 & 7 & 0,2 & 80 & $7.509 .085,24$ & 100 & 9 & 0,1 & 100 & $1.405 .949,85$ \\
\hline 200 & 8 & 0,2 & 80 & $5.325 .655,58$ & 100 & 10 & 0,1 & 100 & $2.755 .676,51$ \\
\hline 200 & 9 & 0,2 & 80 & $4.442 .186,32$ & 100 & 5 & 0,2 & 100 & $9.274 .018,97$ \\
\hline 200 & 10 & 0,2 & 80 & $2.328 .298,59$ & 100 & 6 & 0,2 & 100 & $8.607 .617,83$ \\
\hline 100 & 5 & 0,1 & 90 & $9.513 .573,49$ & 100 & 7 & 0,2 & 100 & $5.831 .401,38$ \\
\hline 100 & 6 & 0,1 & 90 & $7.248 .119,36$ & 100 & 8 & 0,2 & 100 & $4.939 .603,47$ \\
\hline 100 & 7 & 0,1 & 90 & $5.676 .296,09$ & 100 & 9 & 0,2 & 100 & $2.591 .211,83$ \\
\hline 100 & 8 & 0,1 & 90 & $3.666 .695,73$ & 100 & 10 & 0,2 & 100 & $554.962,74$ \\
\hline 100 & 9 & 0,1 & 90 & $2.935 .093,94$ & 200 & 5 & 0,1 & 100 & $9.616 .212,48$ \\
\hline 100 & 10 & 0,1 & 90 & $4.536 .308,05$ & 200 & 6 & 0,1 & 100 & $7.507 .852,13$ \\
\hline 100 & 5 & 0,2 & 90 & $9.623 .167,00$ & 200 & 7 & 0,1 & 100 & $6.649 .349,20$ \\
\hline 100 & 6 & 0,2 & 90 & $8.356 .454,22$ & 200 & 8 & 0,1 & 100 & $4.537 .474,60$ \\
\hline 100 & 7 & 0,2 & 90 & $6.144 .304,72$ & 200 & 9 & 0,1 & 100 & $1.680 .822,62$ \\
\hline 100 & 8 & 0,2 & 90 & $3.640 .678,00$ & 200 & 10 & 0,1 & 100 & $5.448 .289,30$ \\
\hline 100 & 9 & 0,2 & 90 & $3.377 .985,92$ & 200 & 5 & 0,2 & 100 & $10.731 .564,00$ \\
\hline 100 & 10 & 0,2 & 90 & $2.125 .227,84$ & 200 & 6 & 0,2 & 100 & $8.955 .408,16$ \\
\hline 200 & 5 & 0,1 & 90 & $10.800 .109,20$ & 200 & 7 & 0,2 & 100 & $8.190 .314,90$ \\
\hline 200 & 6 & 0,1 & 90 & $8.610 .784,06$ & 200 & 8 & 0,2 & 100 & $6.329 .798,34$ \\
\hline 200 & 7 & 0,1 & 90 & $6.291 .554,24$ & 200 & 9 & 0,2 & 100 & $3.372 .126,88$ \\
\hline 200 & 8 & 0,1 & 90 & $6.820 .766,45$ & & & & & \\
\hline 200 & 9 & 0,1 & 90 & $3.915 .971,32$ & & & & & \\
\hline
\end{tabular}

